\title{
Study On Application Of Safety and Health Management System Based On SMK3 PP NO. 50, 2012 at PT. BITE, Bandung, West Java
}

\author{
Nur Ani* \\ Faculty of Public Health, University of Veteran Bangun Nusantara Sukoharjo, Indonesia \\ aninurk3@gmail.com
}

\begin{abstract}
SMK3 became important and an integral part of the management system. SMK3 is basically a necessity for every human being. Effort increased protection for workers are strong impetus to improve poor labor condition in Indonesia. One such effort is the protection of occupational safety and health (Soehatman Ramli, 2010). The purpose of this studied to review and evaluate and provide an overview of the results application of SMK3 in PT. BITE based on SMK3 PP No. 50, 2012. The research method used qualitative with data collection technique carried out by interview and observation used an instrument in the form checklist SMK3 PP No. 50, 2012 to obtained primary data and secondary data. Data validity used triangulation test. The results of this studied indicated the level of SMK3 compliance at PT. BITE, Bandung at the initial level assessment (64 criteria) by 86\% (2018 observationed) and at the advanced level assessment (166 criteria) by $80 \%$ (2020 observation now). This shown the existence of continuous improvement effort at PT. BITE in an effort to improve the welfare of workforce in the form achievied SMK3 application which is considered good.
\end{abstract}

Key Words: Implementation, OSH Management System, and SMK3 PP No. 50, 2012

Received February, 20, 2020; Revised April 24, 2020; Accepted May 1, 2020 


\section{INTRODUCTION}

Occupational Safety and Health Management System (SMK3) in practice is still often ignored, especially in small and medium-sized companies. This is indicated by the high level of accidents both at work and on the trip. Based on data from the International Labor Organization (ILO), in a vulnerable period of time per year there are 99,000 accidents at work and 70\% of them are life-long disabilities. Based on ILO data in 2013, 1 worker in the world dies every 15 seconds due to work accidents and 160 workers experience work-related illness. In addition, the ILO (2012) also recorded as many as 2 million cases each year experiencing Occupational Diseases (PAK).

Data in Indonesia, the number of work accidents shows an increasing trend. In 2017 the number of reports work accidents was 123,041 cases, while in 2018 it reached 173,105 cases, so that SMK3 become an important and integral part of the management system. SMK3 is basically a necessity for every human being. Efforts to increase protection for workers are strong incentive to improve poor labor conditions in Indonesia. One such effort is the protection of occupational safety and health (Soehatman Ramli, 2010).

Based on the results of Laela Fitriana's research (2017), the application of SMK3 in PT Ahmadaris (a cotton production company) shows a compliance rate of $60.9 \%$ (initial level criteria). Another study conducted by Eko Wibowo Saputro (2015) shows the level of application in the Faculty of Tecnique UNY in automotive workshop (73.57\%). This shows the lack of implementation of SMK3 in companies, especially in manufacturing and pabrication businesses. The lack of application of SMK3 will have an impact on work productivity and the emergence of work accidents and PAK so that the level of labor welfare is not guaranteed. This allows ineffective and inefficient performance improvements in the work process. Based on this background, the researchers conducted a study on application of Occupational Health Safety based on SMK3 PP No. 50, 2012 with initial level assessment (criterion 64) and advanced (criterion 166). This research the conducts at PT. BITE, Bandung, which is a manufacturing and pabrication company that manufactures parts to supply textile, automotive, ceramics and other products made from rubber, polyurethane and metal. The purpose of this study is to review and evaluate and provide an overview of the results of the application of SMK3 in PT. BITE based on SMK3 PP No.50, 2012.

\section{METHODS}

This research is a type of qualitative research used a descriptive phenomenological approach. Data source sampling technique is purposive with data processing using Microsoft Office Excel 2010 Software. The purpose of this studied to describe phenomena descriptively from the experience of participants during interacting with researchers and describe the level of application of SMK3 in the scope of the company. This research was conducting at PT BITE, Bandung, West Java through 2 stages. The first phase carried out in April 2018 (assessment of criteria 64) and the second stage carried out in February 2020 (evaluation of criteria 166) with 13 respondents appointed to represent each of the company's divisions.

The data collection technique carried out by interview and observation used by an instrument form the checklist SMK3 PP No. 50, 2012 to obtain primary data and secondary data. Primary data is the result of observation and in-depth interviews while secondary data is obtained from documents that already exist in the company. This research variable focused on the guidelines for the implementation of the SMK3 PP No. 50, 2012 based on criteria 64 and criteria 166. 


\section{STRADA Jurnal Ilmiah Kesehatan}

DOI: $10.30994 /$ sjik.v9i1.283

ISSN: 2252-3847 (print); 2614-350X (online)

The test validity of data, researchers used triangulation technique's (sources, methods, researchers, theories). Where the triangulation used by comparing the results of interviews and observations with some non-technical literature documents in the form of documents and reports on the Occupational Safety and Health Management System at PT. BITE Bandung with the following stages:

(1) Comparing the results of observationed and interviewed with the SMK3 PP No. 50, 2012, interviewed with the contents of a related document.

Data analysis is done inductively by analyzing data to got conclusions from the results of research used interactive models. This analysis process took place during the research process which undertaken through a series of processes of reduction, data presentation and data verification (Sugiyono, 2010)

\section{RESULTS}

\section{Characteristics of Respondents}

Described the interviewees in terms of education and gender as well as the number of employees in PT. BITE, Bandung. The results can be seen in table 1 and 2 in the below;

Table 1. Characteristics of Respondents

\begin{tabular}{|l|l|c|c|c|}
\hline No. & Organisation Structure & Gender & Education & Amount \\
\hline 1 & Top Manajemen/ direktur & Male & Bachelor Degree (B.D.) & 1 \\
\hline 2 & Manajer QHSE & Male & Senior High School (S.H.S) & 1 \\
\hline 3 & HSE Officer & Female & (B.D.) & 1 \\
\hline 4 & Spv. Produksi \& QC & Male & (S.H.S) & 1 \\
\hline 5 & Spv. Warehouse & Male & (S.H.S) & 1 \\
\hline 6 & Spv. Engginering & Male & (B.D.) & 1 \\
\hline 7 & Staff Engginering & Male & (B.D.) & 1 \\
\hline 8 & Staff QC & Male & (S.H.S) & 1 \\
\hline 9 & Staff Marketing & Female & (S.H.S) & 1 \\
\hline 10 & Staff Purchasing & Female & (B.D.) & 1 \\
\hline 11 & Finance & Female & (S.H.S) & 1 \\
\hline 12 & Accounting & Female & (B.D.) & 1 \\
\hline 13 & HRGA & Male & (S.H.S) & 1 \\
\hline \multicolumn{2}{|c|}{ Number of Respondens } & $\mathbf{1 3 ~ p e o p l e ~}$ \\
\hline
\end{tabular}

Table 2. Number of Employees PT. BITE

\begin{tabular}{|l|c|c|}
\hline No. & Wilayah/ Areas & Amount (n) \\
\hline 1 & Plant 1 dan 2 & 45 \\
\hline 2 & Plant 3 & 33 \\
\hline \multicolumn{2}{|c|}{ Amount } & $\mathbf{7 8}$ \\
\hline
\end{tabular}

Based on tables 1 and 2 above, it known that the informant is a direct representative who organizes facilities and responsible for PT. BITE from top management and division representative. The total number of employees according from HRGA data's is 78 employees. The number of informants who represented the observationed and interviewed were 13 people. 
STRADA Jurnal Ilmiah Kesehatan

DOI: $10.30994 /$ sjik.v9i1.283

ISSN: 2252-3847 (print); 2614-350X (online)

Vol.9 No.1. May 2020. Page.258-265

From a number of informants, it was founding that they had a bachelor degree $(46.2 \%)$ and a vocational school $(46.8 \%)$ with male sex $(61.5 \%)$ and female $(38.5 \%)$.

Compliance of SMK3 PP No. 50, 2012 based on Criteria 64

Criteria 64 is an SMK3 assessment with an initial level category with assessment standards 0 $59 \%$ (Less), 60-84\% (Good) and 85-100\% (Satisfactory). The results of the compliance analysis can be seen in table 3 below;

Table 3. Application Compliance Level of OHS

Based on SMK3 PP NO. 50, 2012 of criteria 64

PT. BITE Bandung, West Java

\begin{tabular}{|c|c|c|c|c|c|c|c|}
\hline \multirow[t]{2}{*}{ No } & \multirow{2}{*}{$\begin{array}{c}\text { Criteria 64 } \\
\text { SMK3 PP No. 50, } 2012\end{array}$} & \multicolumn{2}{|c|}{$\begin{array}{c}\text { Suitabilit } \\
\mathbf{y}\end{array}$} & \multicolumn{2}{|c|}{$\begin{array}{l}\text { Incompati } \\
\text { bility }\end{array}$} & \multirow{2}{*}{$\begin{array}{c}\text { Criteria } \\
\text { Amount } \\
(\mathbf{N})\end{array}$} & \multirow[t]{2}{*}{ Remarks } \\
\hline & & (n) & $(\%)$ & (n) & $(\%)$ & & \\
\hline 1 & $\begin{array}{l}\text { Commitment Development } \\
\text { and Maintenance }\end{array}$ & 13 & 87 & 2 & 13,3 & 15 & $1.3 .3 ; 1.4 .5$ \\
\hline 2 & $\begin{array}{l}\text { Making and Documenting } \\
\text { of OHS Plans }\end{array}$ & 1 & 50 & 1 & 50 & 2 & 2.4 .1 \\
\hline 3 & Design and contract control & 2 & 100 & 0 & 0 & 2 & \\
\hline 4 & Document Control & 1 & 100 & 0 & 0 & 1 & \\
\hline 5 & $\begin{array}{lll}\text { Product } & \text { Purchasing and } \\
\text { Control } & & \end{array}$ & 3 & 100 & 0 & 0 & 3 & \\
\hline 6 & $\begin{array}{l}\text { Security Based Work of } \\
\text { SMK3 }\end{array}$ & 19 & 90,5 & 2 & 9,5 & 21 & $6.5 .3 ; 6.7 .4$ \\
\hline 7 & Monitoring Standards & 5 & 63 & 3 & 37,5 & 8 & $\begin{array}{c}\text { 7.1.1; } \\
\text { 7.2.2;7.4.1 } \\
\end{array}$ \\
\hline 8 & $\begin{array}{l}\text { Reporting and Correction of } \\
\text { Disadvantages }\end{array}$ & 1 & 100 & 0 & 0 & 1 & \\
\hline 9 & $\begin{array}{l}\text { Management of materials } \\
\text { and their movements }\end{array}$ & 7 & 100 & 0 & 0 & 7 & \\
\hline 10 & $\begin{array}{l}\text { Skills and Ability } \\
\text { Development }\end{array}$ & 3 & 75 & 1 & 25 & 4 & 12.5 .1 \\
\hline & $\begin{array}{l}\text { Percentage of SMK3 } \\
\text { mpliance Level Criteria } 64\end{array}$ & 55 & 86 & 9 & 14 & 64 & \\
\hline
\end{tabular}

Based on table 3, it is known that the level of suitability in compliance the implementation of SMK3 PP No.50, 2012 of criteria 64 at PT. BITE is $86 \%$ while the level of discrepancy is 14\%. Discrepancies were found in several criteria including criteria $1.3 .3 ; 1.4 .5 ; 2.4 .1 ; 6.5 .3$; $6.7 .4 ; 7.1 .1 ; 7.2 .2 ; 7.4 .1$; and 12.5.1. Based on the table, the lowest level of conformity is shown in element 2 about making and documenting the OHS plan (50\%), while a prominent level of discrepancy is shown in element 2 about creating and documenting the OHS plan (50\%) and element 7 regarding monitoring standards. The table also illustrates that in the evaluation of 
STRADA Jurnal Ilmiah Kesehatan

DOI: $10.30994 /$ sjik.v9i1.283

ISSN: 2252-3847 (print); 2614-350X (online)

Vol.9 No.1. May 2020. Page.258-265

SMK3 PP No.50, 2012 criteria of 64 specific in elements 10 and 11 were'nt the focus of the assessment.

Compliance of SMK3 PP No. 50, 2012 based on Criteria 166

Criteria 166 is an SMK3 assessment with an advanced level category with assessment standards 0 - 59\% (Less), 60-84\% (Good) and 85-100\% (Satisfactory). The results of the compliance analysis can be seen in table 4 below;

Table 4. Application Compliance Level of OHS

Based on SMK3 PP NO. 50, 2012 of criteria 166

PT. BITE Bandung, West Java

\begin{tabular}{|c|c|c|c|c|c|c|c|}
\hline \multirow{2}{*}{ No } & \multirow{2}{*}{$\begin{array}{c}\text { Criteria } 166 \\
\text { SMK3 PP No. 50, } \\
2012 \\
\end{array}$} & \multicolumn{2}{|c|}{ Suitability } & \multicolumn{2}{|c|}{ Incompatibility } & \multirow{2}{*}{$\begin{array}{c}\text { Criteria } \\
\text { Amount } \\
(\mathbf{N})\end{array}$} & \multirow{2}{*}{ Remarks } \\
\hline & & (f) & $(\%)$ & (f) & $(\%)$ & & \\
\hline 1 & $\begin{array}{l}\text { Commitment } \\
\text { Development and } \\
\text { Maintenance }\end{array}$ & 22 & 85 & 4 & 15 & 26 & $\begin{array}{c}\text { 1.2.3; } 1.3 ; \\
1.4 .2 ; 1.4 .5\end{array}$ \\
\hline 2 & $\begin{array}{l}\text { Making and } \\
\text { Documenting of } \\
\text { OHS Plans }\end{array}$ & 13 & 93 & 1 & 7 & 14 & 2.4 .1 \\
\hline 3 & $\begin{array}{l}\text { Design and contract } \\
\text { control }\end{array}$ & 8 & 100 & 0 & 0 & 8 & - \\
\hline 4 & Document Control & 6 & 86 & 1 & 14 & 7 & 4.1 .4 \\
\hline 5 & $\begin{array}{l}\text { Product Purchasing } \\
\text { and Control }\end{array}$ & 8 & 89 & 1 & 11 & 9 & 5.1 .1 \\
\hline 6 & $\begin{array}{l}\text { Security Based } \\
\text { Work of SMK3 }\end{array}$ & 32 & 78 & 9 & 22 & 41 & $\begin{array}{l}\text { 6.1.5; 6.2.5; } \\
\text { 6.5.3; 6.5.4; } \\
\text { 6.5.6; 6.7.3; } \\
\text { 6.7.4; 6.8.2; } \\
\quad 6.9 .1 \\
\end{array}$ \\
\hline 7 & $\begin{array}{l}\text { Monitoring } \\
\text { Standards }\end{array}$ & 11 & 65 & 6 & 35 & 17 & $\begin{array}{l}\text { 7.1.7; 7.2.1; } \\
\text { 7.2.2; 7.2.3; } \\
\text { 7.4.1; 7.4.5 }\end{array}$ \\
\hline 8 & $\begin{array}{l}\text { Reporting and } \\
\text { Correction of } \\
\text { Disadvantages }\end{array}$ & 8 & 89 & 1 & 11 & 9 & 8.4 .1 \\
\hline 9 & $\begin{array}{l}\text { Management of } \\
\text { materials and their } \\
\text { movements }\end{array}$ & 7 & 58 & 5 & 42 & 12 & $\begin{array}{c}\text { 9.2.1; 9.2.2; } \\
\text { 9.2.3; 9.3.1; } \\
\text { 9.3.2 }\end{array}$ \\
\hline 10 & $\begin{array}{l}\text { Collection and Use } \\
\text { of Services }\end{array}$ & 5 & 83 & 1 & 17 & 6 & - \\
\hline 11 & SMK3 Audit & 2 & 67 & 1 & 33 & 3 & 11.1 .2 \\
\hline
\end{tabular}


STRADA Jurnal Ilmiah Kesehatan

DOI: $10.30994 /$ sjik.v9i1.283

ISSN: 2252-3847 (print); 2614-350X (online)

Vol.9 No.1. May 2020. Page.258-265

\begin{tabular}{|c|c|c|c|c|c|c|c|}
\hline \multirow{2}{*}{ No } & \multicolumn{2}{|c|}{ Criteria 166 } & \multicolumn{2}{|c|}{ Suitability } & \multicolumn{2}{|c|}{ Incompatibility } & \multicolumn{2}{c|}{$\begin{array}{c}\text { Criteria } \\
\text { Amount }\end{array}$} & \multirow{2}{*}{ Remarks } \\
\cline { 2 - 6 } & $\begin{array}{c}\text { SMK3 PP No. 50, } \\
\mathbf{2 0 1 2}\end{array}$ & $\mathbf{( f )}$ & $\mathbf{( \% )}$ & $\mathbf{( f )}$ & $\mathbf{( \% )}$ & \multirow{2}{*}{$(\mathbf{N})$} & \\
\hline 12 & $\begin{array}{l}\text { Skills and Ability } \\
\text { Development }\end{array}$ & 10 & 71 & 4 & 29 & 14 & $\begin{array}{c}12.1 .7 ; 12.2 .2 ; \\
12.3 .3 ; 12.5 .1\end{array}$ \\
\cline { 1 - 5 } $\begin{array}{c}\text { Percentage of SMK3 } \\
\text { Compliance Level } \\
\text { Criteria 166 }\end{array}$ & 132 & $\mathbf{8 0}$ & 34 & 20 & 166 & \\
\hline
\end{tabular}

Based on table 4, it known that the level of conformity in compliance the implementation of SMK3 PP No.50, 2012 of criteria 166 in PT. BITE is $80 \%$ while the level of discrepancy is $20 \%$. The table also shows that the highest discrepancy in compliance SMK3 comes from element 9 , which is about the management of material and its displacement, which has only been complianced by $42 \%$. In this table illustrated that in the evaluation of SMK3 PP No.50, 2012 of criteria 166 assessments are based on 12 elements.

\section{DISCUSSION}

The compliance level of the implementation of SMK3 PP No. 50, 2012 of criteria 64 at PT. BITE of $86 \%$ showed satisfactory value. However, this value doesn't serve as a measure that the standard of implementation will always be guarantee so it is also necessary to pay attention to the deficiencies that have'nt been met as mentioned in elements 2 and 7 which show very poor compliance values. In element 2 the highest discrepancy shown in the absence of documents that are able to trace existence of evidence socialization of the implementation HIRA training and HIRA socialization to all workers. HIRA is a risk assessment tool to determine the level of potential hazards in the workplace. HIRA becomes very important so it needs to be socialized to all workers so that the workforce can work calmly, comfortably and always be vigilant if a potential danger arises. HIRA is part of risk management which refers to ISO 31000: 2018 standards. So element 2 emphasizes that every work plan that has been carried out must be proven in the form documents of photographs, presences, minutes etc, in the form of hardcopy and softcopy.

Another striking discrepancy mentioned in element 7 is the company known to have'nt carried out regular health monitoring and work environment measurements. Health monitoring can be carried out at the beginning before work, once a yearly and specifically annually. This is accordance with Ministerial Regulation; Permenaker No. Per. 03/ MEN/ 1982 which states that companies are required to provide occupational health services. Meanwhile, the measurement of the work environment has'nt been carried out regularly by the company. This is due to the absence of qualified experts and the lack of awareness from the top management that it's important to take measurements the work environment. This work environment measurement is an obligation that must be carried out in accordance with regulation of Permenkes No. 70, 2016 about Standards and requirements for industrial work environment health and in accordance with Regulation; Permenaker RI No. 5, 2018 about Occupational Safety and Health at Work Environment. 


\section{STRADA Jurnal Ilmiah Kesehatan}

DOI: $10.30994 /$ sjik.v9i1.283

Furthermore, the level of compliance of the implementation of SMK3 PP No. 50, 2012 advanced assessment (criterion 166) at PT. BITE shown good results (80\%), this proves the existence of real work as an effort to continuously improve the application of the OSH management system at PT. BITE in the last 2 years. In addition, the level of noncompliance which remains a problem of 20\%. The discrepancy appears dominant originating from element 9, which is about material management and its movement. Where in this element the company hasn't appointed a competent chemist. The company also has'nt provided training to employees (designated chemical officers) in handling transportation, storage and disposal of hazardous and toxic materials and non- hazardous and toxic material, providing training for chemical officers. In addition, the company also has'nt provided SOP on the transportation, storage and disposal of hazardous chemical waste. In this matter relating to the Decree of the Minister of Manpower Number: Kep.187/Men /1999 about Control of Hazardous Chemicals in the Workplace and Regulation PP. RI No.101, 2014 about Management of Hazardous and Toxic Waste. To realize the application of this regulation requires commitment from top management and cooperation from all parties of the workforce.

\section{CONCLUSION}

Application of SMK3 PP No.50, 2012 at PT. BITE at the initial assessment (86\%) and at the advanced level (80\%). This is the result of achieving good application. Therefore, to be even better in the process of improvement needs to be supported by high commitment from top management. In addition, time became conclusive evidence in the process of continuous improvement.

\section{REFERENCE}

BPJS. (2019). Work Accident Rates Tend to Increase, BPJS Employment Pay Compensation of IDR 1.2 Trillion. Downloaded on January 16, 2019 from https://www.bpjsketenagakoperasi.go.id/berita/23322/Angka-Kalam-Kerja-Cender

Dwijayanti, Yulifa D. (2012). Implementation of Occupational Safety and Health Management System (SMK3) at PT. Suka Jaya Makmur, West Kalimantan. West Java: Faculty of Forestry Bogor Institute of Agriculture Press.

Fitriana, Laela., Wahyuningsih, Anik S. (2017). Implementation of Occupational Health and Safety Management System (SMK3) in PT. Ahmadaris. HIGEIA (Juornal of Publich Health Research and Development. Http://journal.unnes.ac.id/sju/index.php/higeia.

Huzain, Mohamad Reza. (2013). Assessment Analysis of Fulfillment of Occupational Safety and Health Management System (SMK3) PP No. 50, 2012 at PT. X Semarang. JKM (Journal of Public Health) Volume 2, Number 1, January 2013. Online: http://ejournals1.undip.ac.id/index.php/jkm.

Ministry of Manpower RI. (2018). Per-Menaker RI No. 5, 2018 about Occupational Safety and Health at Work Environment. Jakarta: Ministry of Manpower Republic of Indonesia Press.

Pangkey, Febyana., Malingkas, Grace Y., Walangitan, D.O.R. (2012). Application of Occupational Safety and Health Management System (SMK3) to the Construction Project in Indonesia (Case Study: Bridge Construction Dr. Ir. Soekarno-Manado). Junal Scientific MEDIA ENGINEERING Vol. 2, No. 2, July 2012. ISSN 2087-9334 (100-113). 


\section{STRADA Jurnal Ilmiah Kesehatan}

DOI: $10.30994 /$ sjik.v9i1.283

ISSN: 2252-3847 (print); 2614-350X (online)

Vol.9 No.1. May 2020. Page.258-265

Government regulations. (2012). SMK3 PP No. 50, 2012 about of OSH Management System. Jakarta: Ministry of Manpower Republic of Indonesia Press.

Government regulations. Control of Hazardous Chemicals in the Workplace and Regulations

Government regulations. (2014). PP RI No. 101, 2014 concerning Management of Hazardous and Toxic Waste. Downloaded on January 16, 2020 https://toolsfortransformation.net/wp-content/uploads/2017/05/PP_NO_101_2014Management-limbah-B3_E.pdf.

Ministerial regulation. (1982). Permenaker No. Per. 03 / MEN / 1982 about Occupational Health Services in the Workplace. Jakarta.

Ramli, Soehatman. (2010). Practical Guidelines for Risk Management in OSH Perspective. Jakarta: Dian Rakyat Press.

Saputro, Eko Wibowo. (2015). Application of Occupational Safety and Health Management System (SMK3) as an Effort to Prevent Occupational Accidents at the Automotive Workshop, Faculty of Engineering, University of Yogyakarta State. Yogyakarta: UNY Press.

Sugiyono (2010). Qualitative Quantitative Research Methods, and R \& D. Bandung: Harapan Press 